Kaygl, 19(II)/2020: 636-653. Araştırma Makalesi | Research Article

Makale Geliş | Received: 27.07.2020

Makale Kabul | Accepted: 31.08.2020

Yayın Tarihi | Publication Date: 15.09.2020

DOI: 10.20981/kaygi.792057

\title{
Yavuz KILIÇ
}

Prof. Dr. |Prof. Dr.

Aydın Adnan Menderes Üniversitesi, Fen-Edebiyat Fakültesi, Felsefe Bölümü, Aydın, TR. Aydın Adnan Menderes University, Faculty of Arts and Sciences, Department of Philosophy, Aydın, TR.

ORCID: 0000-0002-2948-9810

ykilic@adu.edu.tr

Burak SAYIN

Arş. Gör. | Res. Assist Aydın Adnan Menderes Üniversitesi, Fen-Edebiyat Fakültesi, Felsefe Bölümü, Aydın, TR. Aydın Adnan Menderes University, Faculty of Arts and Sciences, Department of Philosophy, Aydın, TR.

ORCID: 0000-0001-9618-2758

burak.sayin@adu.edu.tr

\section{Benedetto Croce'nin Felsefesinde Sezgi-İfade Özdeşliği Bakımından Sanatın Konumu}

\section{Öz}

Benedetto Croce'ye göre sezgi, tüm bilme tecrübemizin temelini oluşturması bakımından en önemli bilgi formudur. Hakiki sezgiyi; yani Tinsel olguyu daha alt seviyede bulunan pasiflikten veya başka bir deyişle Tin'den yoksun salt doğallıktan ayırt etmemizi sağlayan kesin dayanak, sezginin ifadeyle özdeş olmasıdır. Croce'nin felsefesine, estetik ve bilgi problemi bakımından özgün karakterini veren bu özdeşlik aynı zamanda bazı problemlere de yol açar. Croce her hakiki sezginin ifade edilmiş olmak şartıyla gerçek olduğunu, dolayısıyla sezgi ile ifadenin birbirinden ayrılamaz olduğunu ileri sürerken hem tek tek bireysel şeylerin hem zihnimizdeki imgelerin hem de ifadenin en mükemmel formu olması bakımından sanat eserinin de sezgi olduğunu belirtir. Ancak sezgi ve ifade özdeş, yani birbirinden ayrılamaz ise ifade edilebilir olması ve bilgi değeri bakımından bireysel bir olgu ile bir sanat eserinde ortaya çımış mükemmel bir ifade arasında nasıl bir fark gözetmemiz gerektiği, üzerinde durulması gereken bir noktadır. Bu makalede Croce'nin sezgi ve ifade kavramları söz konusu problem ekseninde ele alınarak, sanat eserinin neden diğer sezgi türleriyle aynı cinsten olmadığı ortaya konulacaktır.

Anahtar Kelimeler: Sezgi, İfade, Sanat, İzlenim, Bilgi, Tin, Temsil.

\section{The Position of Art in terms of Intutition-Expression Identity in the Benedetto Croce's Philosophical Thought}

\footnotetext{
Abstract

According to Benedetto Croce, intuition is the most important form of knowledge since it underlies our knowing experience. The identity of intuition and expression is the basis which enables us to distinguish real intuition, that is to say, the spiritual phenomenon from passivity, the lower state of things meaning pure naturalism devoid of the Spirit. This identity gives Croce's philosophy its original character regarding aesthetics and the problem of knowledge as well as emerging diverse problems. Croce argues that real intuition can exist only if it is expressed and therefore intuition and expression are indivisible. Alongside the individual things and the images in our minds, the work of art is also intuition since it is the perfect form of expression. If intuition and expression are identical, meaning indivisible, the difference between expressibility and an individual fact in respect to value of knowledge and a perfect expression in a work of art is an important point worth considering. In this article, we will discuss Croce's
} 
concepts of intutition and expression regarding the problem in question and we will suggest that a work of art is not the same with other types of intution.

Keywords: Intutition, Expression, Art, Impresion, Knowledge, Spirit, Representation.

\section{Giriş}

Benedetto Croce 1902 y1lında Ifade Bilimi ve Genel Dilbilim Olarak Estetik (Estetica come Scienza dell'espressione e Linguistica Generale) başlıklı büyük eserini yayımladi. Bu yapıt, onun dört kitaptan oluşan Tin Felsefesi'nin (Filosofia dello Spirito) ilk kitabıdır. Tin kavramı, Alman İdealizmi ve özellikle Hegel etkileri taşıyan Croce’nin felsefesinin temelini ve aslında dünyayı açıklayan bütün sistemin bizzat kendisini oluşturur. Estetica'dan sonra gelen kitaplar; Saf Kavram Bilimi Olarak Mantık (Logica come Scienza del Concetto Puro), Pratik Olanın Felsefesi: Ekonomi ve Etik (Filosofia della Pratica: Economica ed Etica) ve Tarihyazımının Teorisi ve Tarihi (Teoria e Storia della Storiografia) olarak sıralanır. Bu eserlerin başlıklarını belirleyen mantık, ekonomi ve etik, nihayetinde de tarih kavramları, hakikati ifade eden Tin'in içinde organik bir biçimde ele alındıkları takdirde anlaşılır hale gelir. Estetik'in temel iddiası olan, sezgi bilgisinin kavramsal bilgi başta olmak üzere tüm bilgimizin temelini oluşturduğu argümanıyla uyumlu biçimde, söz konusu eser de dört kitaplık soruşturmanın sadece kronolojik bakımdan değil, temeli olması bakımından da ilk sıradadır. Dolayısıyla Croce'nin sezgiyi tüm bilgimizin temeline oturtması, insana ait bilgi alanlarını ele alırken her zaman belirli bir hareket noktasına sahip olmamızı gerektirir. Ancak tek bir tür bilgi olmadığına göre, sezginin bu bilgi türleri bakımından hem konumu hem ele alınması dikkat gerektiren bir duruma işaret eder. Zira tinsel olanın hakiki, Tin'den yoksun olan salt maddenin ise pasiflik ve hayvanilik olduğunu öne süren Croce (Croce, 1990: 9), bu farkı oluşturmak üzere, bir diğer önemli kavramı olan ifadeye başvurur ve sezginin ifade edildiği takdirde hakiki olduğunu, dolayısıyla sezgi ve ifadenin bu bakımdan özdeşliğini ortaya koyar. Ancak bir yandan da hem tek tek bireysel şeylerin hem de sanat eserlerinin sezgi olduğunu öne sürer. Bu bakımdan olsa gerek, Croce'nin sezgi hakkında söylediklerini anlamak zorlaşmaktadır. 
Bu makalede amacımız, sanat eseri ile tekil bir nesne arasındaki farkı Croce'nin görüşleri bağlamında, ama eleştirel bir yaklaşımla irdeleyerek sanat eserinin özgün karakterini ortaya koymaktır. Bunun için başta sezgi ve ifade kavramlarını ele alıp, sonrasında sanatın Croce'nin felsefesi bakımından ne anlama geldiğini tartışacağız. Nihayetinde ise sanatsal ifade ile gündelik sezgiye ilişkin ifadenin karşılaştırmasını yaparak sanat eserinin neden farklı olduğunu açıklamaya çalışacağız.

\section{Sezgi, İfade ve Sanat Özdeşliği}

Croce'nin felsefe dizgesini ele alırken, sezgi kavramı hareket noktamız olmak durumundadır. Ona göre

"Bilginin iki formu vardır: sezgi bilgisi ya da mantık bilgisi; hayal gücü yoluyla edinilen bilgi ya da zihin yoluyla edinilen bilgi; bireysel olanın bilgisi ya da tümel olanın bilgisi; tek tek şeylerin bilgisi ya da onların arasındaki ilişkinin bilgisi; özetle bilgi ya imgeler ya da kavramlar meydana getirir" (Croce, 1990: 3).

Croce sezgiden kendisinin de altını çizdiği üzere bir bilgi formunu anlar ve üstelik bu, mantık bilgisi veya kavramsal bilgi olarak adlandırdığı ve içine felsefenin de girdiği bilgi türünün varlığı için zorunlu olması bakımından temel bir bilgiyi teşkil eder. Kavramlara dayanan bilgi "nesneler arasındaki ilişkilerin bilgisidir ve nesneler de sezgilerdir. Sezgiler olmadan kavramlar mümkün değildir; tıpkı izlenim materyali olmadan sezginin de olamayacağı gibi” (Croce, 1990: 29). O halde tekil nesneler sezgidir ve bunlar arasında zihnimizde kurulan ilişskiler de bizim kavramsal bilgimizi oluşturur. Peki bu kitabın, bu kalemin vb. sezgi olması tam olarak ne anlama gelir? Paul Carus'a göre Croce'nin sezgi kavrayıșı, mistik metinlerdeki sezgiden ve Kant'ın kavrayışından farklıdır. Mistik sezgide "sezgiler şaire Tanrıdan gelen vahiyler olarak betimlenir ve bu yüzden şair, düşüncelerini kendi oluşturduğunu değil, onları keşfettiğini ileri sürer” iken "Kant'ın Anschauung kavramı çok farklıdır. Onda mistik düşünceden en ufak bir iz bulunmaz. O görme duyusuna ilişskindir ve karşılığı olarak sık sık 'duyum’ sözcügü de kullanılır” (Carus, 1916: 313). Ancak Croce’ye göre sezgi ne salt duyusal olandan ne de şairin sezgisinden ibarettir: 
"Duyum basitçe, duyular tarafından algılanan ham maddedir, sezgi ise Croce'nin 'ifade' dediği kavramı kapsar; yani bir kavramın salt tanımı olarak değil, bütün detaylarıyla ve somut biçimde bireyselleştirilmiş sanatsal bir resim formunda, şiirsel biçimde sunularak somut bir görüntü haline getirilmiş olan şeydir" (Carus, 1916: 314).

Dolayısıyla hem önümde duran kalemin hem zihnimde oluşturduğum kalem imgesinin sezgi olması, bunların ikisinin de somut biçimde ifade edilebilir olmaları bakımındandır. Tekil nesnelerin sezgi olması, kavramsal bilgimizin temelini oluşturan ifade edilebilir unsurlar oldukları anlamına gelir. Yani onlar, salt fiziksel, dolayısıyla Tin'den yoksun pasif elemanlar değildir. Sezgide algıya ilişkin bir yön kesinlikle vardır ancak gerçek ve gerçek olmayan ayrımının sezginin doğasına yabancı olmasından ötürü hem maddi hem maddi olmayan şeyler birer sezgi olabilirler.

"Fiziksel olgular, iç mantıkları ve ortak uzlaşı aracılığıyla bir gerçeklik olarak değil, fakat bilimsel gayelere yönelik zihinsel bir kurgu olarak ortaya çıkarlar" (Croce, 2007: 11). Zira "gerçeklik ve gerçek olmayan arasındaki ayrılık, sezgiye doğası gereği yabancıdır ve ikinci dereceden bir şeydir” (Croce, 1990: 6). Dolayısıyla gerçeklik dediğimiz şeyin (ki bu aslında Tin'dir) özünü teşkil eden sezgi, Croce’ye göre bilimin imkânı için gerekli olan fiziksel dış dünyanın dahil olduğu gerçek-gerçek olmayan ayrımına tabi değildir.

"Bu gerçeklik olan zihin ya da bu zihin olan gerçeklik, formlarını ayırt edebileceğimiz bir etkinliktir; ve bu formların sırası ile ilişkilerini de ayırt edebiliriz; fakat onları birbirinden ayıramayız, çünkü sağlam, organik bir bağlılık ve dayanışma birliği içinde bulunurlar. Gerçeklik bir sistemdir. Felsefenin işi bu etkinlik formlarını ortaya koymak ve süreçleri boyunca somut tecrübe dünyasını oluşturmak üzere nasıl birleştiklerini göstermektir" (Carr, 1917: 8).

Carr'ın zihin ile kast ettiği Tin'dir. Croce'nin kullandığı anlamıyla Tin, kimi zaman zihinle de eş anlamlı kullanılır çünkü aynı zamanda bir ve tek sistem olan Tin, Carr'ın da altını çizdiği üzere bir etkinlik ve bu etkinliğin temelleri de sezgiye dayanmaktadır. O halde gerçekliğin Tin/zihin ile ifade edilen bir sistem olduğu ve bu sistemin de kendi içinde birbirine bağımlı ancak birbirinden koparılamaz etkinlik formlarından oluşan organik bir bütünlük olduğu kavrandığg takdirde, fiziksel dünyanın neden özünde gerçek 
değil kurgusal, gerçek-gerçek olmayan ayrımının da sezgiye (yani Tin'in temellerini oluşturan öğeye) neden ikincil olduğu anlaş1lır hale gelir.

Peki sezginin ayırt edici niteliği nedir? Gerçek ve gerçek olmayan ayrılığı ona ait olmadığına göre, o gerçeğe ilişkin bilindik kavrayıştan farklı bir zeminde ele alınmalıdır. Croce'ye göre,

"Hakiki sezgiyi ... daha alt seviyede olan şeyden: Tinsel eylemi mekanik, pasif, doğal olgudan ayıran güvenilir bir yol vardır. Her hakiki sezgi veya temsil aynı zamanda ifadedir. Bir ifadede nesnelleşmemiş olan şey sezgi veya temsil değil, ancak duyum ve doğallıktır. Tin eylemeden, biçim vermeden, ifade etmeden sezgi ile bilemez (intuire). Sezgiyi ifadeden ayıran kişi onları bir daha bir araya getirmeyi başaramaz" (Croce, 1990: 12).

Croce'nin sezgi kavrayışına özgün karakterini veren nokta işte bu özdeşliktir. Yani sezgi dediğimizde ifadeyi, ifade dediğimizde sezgiyi anlamamız gerekir ve bu iki kavram birbirinden ayrı olarak düşünülemez, çünkü

"Bedeni zihinden, içsel olanı dışsal olandan veya sezgiyi ifadeden ayırırsak, birinden diğerine geçmemiz veya felsefi bir düalizmi (ki Croce'ye göre savunulmazdır) onaylamaksızın onları birleştirmemiz mümkün değildir" (Dimler, 1963: 481).

Burada şu soruyu sorabiliriz: Sezgi ile ifade aynı şey midir, yoksa bu iki sözcük farklılıklara sahip iki kavrama işaret etmelerine karşın birbiri yerine kullanılabilir mi? Wildon Carr'a göre,

"Bilginin ilk temel, basit formu olan sezgi ve insanlığın en genel ve evrensel dili olan ifadenin sanatla özdeşliği, Croce'nin 1srarla üzerinde durduğu bir sanat niteliğini açıklar. Sanat her zaman ve özünde şiirseldir; insan ruhunun dışarı taşması, içinde form verdiği şeyleri ifadeye getirmesidir" (Carr, 1917: 76).

Bu noktada Croce'nin sezgiyi ve ifadeyi sanatla özdeş kılmasının gerekçesinin, şiirsellik, yani sanatın özünde ifade olmasında yattı̆̆ını görüyoruz. Şiirin özünü imgeler oluşturur ve "ifade etmeyen, yani bir söz, şark1, çizim, resim, heykel veya mimari olmayan bir imge var olmayan bir imgedir" (Croce, 2014). Şiirin Croce'nin estetik teorisi bakımından taşıdığı önem ve sanatın özünü oluşturan bir karakter olmasının nedeni bu satırlarda daha açık kılınır. Sanatın özsel niteliği bir imgenin ifadesinde yatar 
ve ifadeye gelmemişse bir imge zaten imge değildir. O zaman tüm sanat aynı zamanda sezgidir ve sezgi de tüm bilgimizin en temel basamağı olduğu için, dünyayı kavrayışımız aslında özünde sanatsaldır. Zira Croce,

"Hepimiz insan doğasının en evrensel yetilerine ve enerjilerine en yüksek derecede sahip olduğumuzdan, aslında hepimizin içinde biraz şair, biraz heykeltıraş, biraz müzisyen, biraz ressam, biraz nesir yazarı yatar: Fakat içimizdeki sanatçı bu sıfatları hakkıyla taşıyanlara kıyasla pek küçüktür"' (Croce, 1965: 11)

Diyerek bütün insanların özünde, yoğunluğu ama az ama çok olan bir sanatçı yattığını öne sürmüş olur. Dolayısıyla Croce'nin sanata yaklaşımı, sanata ve sanatçıya özel bir yetenek veya deha bahşeden görüşten ayrılarak, onu daha kamusal ve genel bir düzlemde ele alma eğilimindedir. Tabii ki Croce, tabiri caizse sıradan insanın içinde yatan şairin, hakiki şaire kıyasla, potansiyelini gerçekleştirip ortaya çıkarmak bakımından aynı ölçüde yetkin olmadığının altını çizmiştir. Ancak onun vurguladığı nokta, herkesin içinde yatmakta olan az ya da çok sanatçı yetisinin, sanat eserinin; yani ifade edilmiş olan hakiki bir sezginin tüm insanlık için kavranabilir, anlaşılabilir olmasında ana etken olduğudur. Sanat eserinin ortaya çıkışında doğa üstü bir yaratıcı dehadan çok niceliksel bir faktör vardır:

"Büyük sanatçılar için, bizi kendimiz için bilinir kıldıkları söylenir. Fakat onlarınkiyle bizim hayal gücümüzün doğası özdeş ve aradaki fark yalnızca niceliksel olmasaydı bu nasıl mümkün olurdu? Poeta nascitur ${ }^{1}$ cümlesini homo nascitur poeta' ya $^{2}$ çevirmek daha iyidir: Bazı insanlar büyük şairler olarak doğar, bazıları küçük. Deha kültü ve ondan çıkan tüm hurafeler bu niceliksel farkın niteliksel olarak anlaşılmasından doğmuştur. Dehanın gökten inen bir şey değil, insanlığın ta kendisi olduğu unutulmuştur" (Croce, 1965: 14-15).

Görüldüğü gibi Croce, bütün insanlığın deha olduğunu söyleyerek, sanatsal yaratıcılık bakımından insanlar arasında bulunması olası her türlü niteliksel fark1 reddetmektedir. Sıklıkla şair örneği üzerinden argümanını götürmesi de yukarıda altını

\footnotetext{
1 “Şair, şair olarak doğar”. Aslı "poeta nascitur, non fit" yani "şair, şair olarak doğar; sonradan olmaz" anlamına gelen Latince söz.

2 “İnsan şair olarak doğar”. Croce, Latin deyişini tersine çevirerek, her insanın biraz şair olduğu fikrine uyarliyor.
} 
çizdiğimiz şiir ve imge kavramları göz önünde bulundurulduğunda şaşırtıcı değildir. İnsanlık, yani Tin'i oluşturan ve Tin'in de kendisinden oluştuğu evrensel zihin olarak insanlık, özünde dehadır ve bireyler arasındaki fark niceliksel bir dehadır. Herkes biraz sanatçı olarak görüldüğünden, ortaya konulan sanat eserlerinin tümü, yani tüm hakiki sezgiler de bütün insanlar tarafından kavranabilir. Dimler'in vurguladığı gibi, insanüstü bir dehanın kabulü durumunda, Croce'nin yine bir düalizm tehlikesi görmüş olabileceği ve bu düalizmden kaçınmak üzere söz konusu tavrını takındığını ileri sürmek de akla yatkın olacaktır. Çünkü sanatçı ve ortaya koyduğu sanat eseri, insanların geri kalanının tabi olmadığı tanrısal, göklerden gelen bir yeteneğe, yani dehaya dayanıyor olsa; Croce için her şeyden önce Tin ile insan arasında giderilmesi mümkün olmayan bir ayrılık ve ontolojik ikilik tehlikesi doğardı. Ayrıca, böyle bir durumda hakiki bir sezgi olan sanat eseri yalnızca Tin'in dokunduğu özel insanlar tarafından anlaşılabilirdi ve geri kalan insanların Tin'e herhangi bir katılımı söz konusu olamazdı. Oysa sezgiyi hem derece hem de mantıksal öncelik bakımından temele koyan Croce'ye göre böyle bir durum söz konusu dahi olamaz; olsa o zaman ideal bir sistemden söz edilemez. Bu tasarımda bilginin bizzat kendisi, olası düalizm sonucu belli bir zümrenin ulaşımına açıkken, geri kalanların asla erişemeyeceği bir evrede kalırdı.

Croce, sezgiyi böyle konumlandırarak, dolayısıyla estetik etkinliği de dünyayı kavrayışımızda kurucu, temel bir düzleme oturtmuş olur. Tunalı bu durumu şöyle ifade eder:

"Bununla şimdiye kadar günlük hayattan ve günlük sezgilerden, hayat gerçeğinden bağımsız kendine özgü, lüx bir etkinlik alanı olarak düşünülen sanat1, Croce, gündelik sezgi bilgisine bağlıyor ve böylece sanatı gündelik hayat gerçeğinin içine sokuyor. ... Croce'nin ulaştı̆̆ bu sonuç, çağdaş estetik teorisi yönünden önemli bir sonuçtur. Çünkü, Croce için estetik bir lüx etkinlik olmayıp, kökü gündelik hayat sezgileri içine girmiş bulunan temel bir etkinliktir" (Tunal1, 1973: 30-31).

Probleme bu perspektiften bakıldığında, Tunalı'nın çıkarımının son derece yerinde olduğu görülecektir. Zira estetiğe, sanata ilişkin satırlarında açıktan açığa politik bir tavır pek sık görülmese de Croce'nin filozof ve estetikçi kimliğinin yanı sıra bilhassa Mussolini döneminde, faşizmin filozofu olarak adlandırılan arkadaşı Giovanni 
Gentile'nin karşısında konumlanarak anti-faşist entelektüel hareketin bir numaralı figürü olarak durduğunu görürüz. Yani Croce'nin kendi yaşamında benimsediği dünya görüşüyle onun estetik kuramı arsında entelektüel bir bağ olduğunu çıkarsamak yanlış olmaz. Nitekim faşist estetik söz konusu olduğunda "güzel ideali bu estetik için merkezidir; ister insan bedenine ilişkin bir güzel olsun ister politik litürjiye dair. Bir güzellik standardına duyulan özlem Avrupalı orta sınıflarda kökleşmiş haldeydi ve 'iyi, doğru ve kutsal' anlamında güzel tanımı faşist kültün önemli bir arka planını teşkil ediyordu" (Mosse, 1996: 246). Oysa Croce'nin estetiğine baktığımızda tam da bunun aksi bir kavrayış görürüz. Güzel hangi alanda olursa olsun, bir kutsiyet ya da doğruluk vaz etmez. Onun temel karakteri ifade gücüdür. Sözgelimi Croce için "her bilimsel yapıt aynı zamanda bir sanat yapıtıdır" da (Croce, 1990: 32). Bunun temel nedeni hakiki bir bilim yapıtının, olabildiğince uygun bir şekilde içeriğini ortaya koyması, yani ifade etmesidir. İşte bu ifade edilebilirlik onun sanatla kesiştiği noktadır ve faşist estetiğin aksine ne bir kutsallık ne de iyilik iddiasındadır. Faşist ideolojinin belirlediği güzel ise hem muazzam ölçüde ayrımcı hem de a priori karakteristikleriyle dünyanın geri kalanını baştan dışarıda bırakan bir yapıdadır. Ancak hem gündelik yaşantımızın ve bilgimizin hem de bütün hakikatin kendisi olan Tin'in temeline oturan sezgi bilgisi, dolayısıyla güzel kavramı ise Mosse'nin vurguladığı gibi, artık belli bir sınıfa değil, tüm insanlığa ait ve herkes tarafından anlaşılabilir bir değer haline gelir. Çünkü onun ana karakteri, kutsallık, iyilik, doğruluk vb. nitelikler değil, son derece basit bir biçimde ifade edilebilir olmasıdır.

\section{Sanatsal Sezgi ve Gündelik Sezgi Farkı}

Gördügümüz üzere Croce'nin estetiğine özgün karakterini veren ifade kavramı, sadece sanat değil, genel bilgi kuramı bakımından da merkezi bir role sahiptir. Onun sezgiyi ele alış tarzı ve bu tarzı destekleyen motivasyonlar kendi içinde son derece tutarlı olmakla birlikte, bazı problemler de oluşturmaktadır. Sanat kavramının tarihsel süreci göz önünde bulundurulduğunda, şüphesiz sanata ilişkin tüm yaklaşımları ya da tanımları ele almamız mümkün değildir. Ancak bu durum, sanatın ve dolayısıyla sanat 
eserinin doğasına dair evrensel olma iddiası taşıyan muhtelif ölçütler savunamayacağımız anlamına da gelmez. Sanatın erekselliği, zanaat ile olan benzerlikleri ve farkları, toplumsal olup olmadığı, ahlaka uygunluğu vb. farklı öğeler çağlar boyunca tartışma konusu olmasına karşın; sanatsal yaratıcılık, sanatın en yüksek değerinin güzel olduğu, sanat dehası gibi kavramlar da sanatın kendisinden neredeyse asla ayrılamaz olan karakteristiklerini oluştururlar. Sözgelimi güzelin ne olduğu, neye güzel denmesi gerektiği tartışılabilir olsa da hakiki bir sanat eserinin güzel olması gerektiği tartışmalı değildir. Çünkü bu tartışma başladığı anda biz sözünü ettiğimiz güzelin alelade bir sözcük değil sanatsal güzel olduğunu biliriz.

Croce'nin bilimsel bir yapıtı da sanat eseri olarak yorumlaması ve aynı zamanda gündelik sezgilerle sanatsal sezgiler arasında da özce bir fark olmaması onun sanat anlayışıyla ilgilidir. O, sanatın bizzat kendisi hakkında da şöyle diyor:

“İnsan izlenimleri işleyerek kendini onlardan kurtarır. Onları nesnelleştirerek kendini onlardan ayırır ve onların efendisi haline gelir. Sanatın kurtarıcı ve arındırıcı işlevi onun başka bir yönüdür ve etkinlik karakterinin başka bir formülüdür. $\mathrm{Bu}$ etkinlik, eylemsizliği ortadan kaldırdığından kesinlikle özgürleştiricidir" (Croce, 1990: 28).

Yani sanatsal etkinliğin özgürleştirici, hatta kurtarıcı karakteri, son tahlilde onun eylemsizliği ortadan kaldırmasında yatar. Eylemsizlik veya pasiflik ise Tin'den yoksunluk anlamına geldiğine göre, aslında sanat özünde sadece Tinsel değil fakat bizzat Tin ile bir olma, onunla bütünleşik olarak anlamlı hale gelen bir etkinlik biçiminde düşünülebilir. Bu durum Breviario'daki şu satırlarda açıkça ortaya çıkar: “Tin' in bütünlügünün gücü vasıtasıyla, sanatta bütün bu adı geçen şeylerle birlikte diğer her şey mevcut olduğundan, sanatta bir kavram, tarih, matematik, ... ve diğer başka bir şey gören haklıdır” (Croce, 2016: 51). Bu söylenen dikkate alındığında, sanatın tüm insan etkinliklerini kapsayan evrensel bir alan olduğu görüşü daha tutarlı hale gelir. Tin insanın yaşamında teorik ve pratik olmak üzere kendini gösterir ve ekonomi, ahlak, felsefe, bilim gibi alanlarda ayırt edilebilir. Ancak sonuçta tüm varlık alanı Mutlak Tin'in bütünlüğü içinde bir anlam kazanır ve dünyayı kavrayışının derece bakımından ilk sırasında estetik sezgi yatan insan için de sanat, bütün bu öğeleri kapsayıcı nitelikte 
bir etkinlik olarak tasarlanır. Bu yaklaşım tabii ki tarihte ilk kez Croce tarafindan benimsenmiş değildir. Doorly de benzer şeyler söylemektedir:

"D'alembert'in açıklamasına göre pozitif kurallara indirgenmesi mümkün olan, kişisel heves, kapris veya fikirlere göre değişiklik göstermeyen her bilgi sistemini bir sanat olarak tanımlıyoruz: dolayısıyla pratikte birçok bilim dalının sanat olarak görülebileceğini söyleyebiliriz” (Doorly, 2019: 59).

Ancak özellikle modern sanatın ortaya çıkışıyla beraber, sanata olan yaklaşım da artık klasik bakış açılarından sıyrılarak daha özgün bir hal almıştır. Dolayısıyla bir sanat eserinde bilimsel öğeler bulunmasının ya da tam tersinin, bilimin sanat ile özdeş olduğu sonucuna ulaşması artık şüpheli bir durumdadır. Öte yandan felsefi bir yarg1 bildirildiğinde ise, bu yargı özü gereği evrensel bir karaktere sahip olduğu için, Croce'nin sanata ilişkin görüşlerinin geçerliliğini çağdaş bir perspektiften sorgulamak haksızlık olmaz. Zira Croce hem yaşadığı dönem itibariyle modern sanata aşinadır hem de en ünlü argümanı "her gerçek tarih çağdaş tarihtir" ifadesi (Croce, 1921: 12), onun insanın varlık alanına yaklaşımını gözler önüne serer. Sanatın veya bir etkinliğin bizzat kendisi üzerine öne sürülmüş bir yargı da dolayısıyla evrensel bir düzlemde ele alınmak zorundadır. Düşünceleri biçimlendiren tarihsel koşulların varlığı gerçektir ama söz konusu koşulların altında şekillenen fikirler veya yargılar nihayetinde evrensel olma iddiasındadirlar.

Croce'nin ortaya koymuş olduğu ifade-sezgi özdeşliği ve sanat bağlantısını daha iyi anlayabilmemiz için, sanatın ne olduğuna ilişkin soruşturmayı, sanatçının doğası, güzel, beğeni gibi ilgili öğeleri daha geniş bir pespektiften ele alarak tekrar yapmak gerekir. Croce sanatsal güzele ilişkin şunları söyler:

"Doğal nesnelerden estetik bir zevk alabilmek için, onlardan dişsal ve tarihsel realitelerinden soyutlamalı, yalın görünüş ve görüntülerini varlıktan ayırmak gerektiği gözlemlenmiştir. ... Doğa, ona sadece sanatçı gözüyle bakanlar için güzeldir; zoologlar ve botanikçiler güzel hayvan ya da çiçek diye bir şey bilmezler; doğal güzel keşfedilir ... yaratıcı hayal gücünün yardımı olmadan doğanın hiçbir parçası güzel değildir" (Croce, 1965: 9899). 
O halde pozitif bir bilim dalının nesnesinde güzel olanı görmek sadece sanatçı gözü diye adlandırılan bir yaklaşım veya yetiyle mümkündür ve bilim insanı bu yetiye sahip değildir. Zira Croce bir botanikçi için güzel çiçek diye bir şey olmayacağını söyleyerek bunu çok açık biçimde ortaya koymuştur. Botanikçi için o çiçek olsa olsa mükemmel bir renk uyumuna veya başka türlü bitkisel özelliklere sahiptir. Ancak bir sanatçının ve bir sanat eserine bakan sanatçı gözüne sahip insanın hissettiği güzel duygusu burada söz konusu değildir. Botanikçi bir çiçeğe baktığında botanikle ilgili nitelikler görür ama Botticelli'nin İlkbahar ${ }^{3}$ tablosuna baktığında gördüğü çiçekler onda güzel duygusu uyandırır. Çünkü bu tabloya bakarken o, artık botanikçi değil, sanatçı görüşüne sahip bir insan olarak esere bakan kişidir. O halde bilim ile sanat arasındaki farkın yanı sıra, Croce'nin düşünce dizgesinde sanatın bilimi kapsayıcı bir yönü de vardır. Öyle ki yaratıcı hayal gücü yoluyla doğada güzeli tesis etmek mümkün iken, bilimsel bir yaklaşımla bilimsel olmayan bir etkinliği bilimsel olarak kavramak mümkün değildir.

Peki güzel nedir? Croce şöyle diyor:

\begin{abstract}
"Güzel yalnızca başarılı bir ifade için değil, bilimsel bir hakikat, başarıyla gerçekleştirilmiş bir eylem ve ahlaki bir eylem için de kullanılır: böylece zihinsel güzelden, güzel eylemden, ahlaki güzelden bahsetmiş oluruz. $\mathrm{Bu}$ sayısız türde kullanım takip edilmeye çalışılırsa, pek çok filozofun ve sanat öğrencisinin yolunu kaybettiği çıkışı olmayan bir dil labirentine girilir. ... Bize güzeli başarılı ifade veya yalnızca ifade olarak tanımlamak makul ve akla yatkın geliyor, zira ifade başarılı olmadığ 1 takdirde ifade değildir" (Croce, 1965: 78-79).
\end{abstract}

Dolayısıyla daha önce vurgulamış olduğumuz gibi, Tin'in kendisi ve onu oluşturan, onun içinde ortaya çıkan her şey güzel olarak adlandırılır. İdealist felsefe açısından bu güzel kavrayışı oldukça anlaşılır bir durumdur. Sözgelimi Hegel’e göre,

\footnotetext{
3 İlgili eser için bkz. https://www.uffizi.it/en/artworks/botticelli-spring. Bu tabloda Botticelli'nin en az 138 farklı bitki çizdiği belirlenmiştir. Bu bilgi bize Botticelli’nin çiçekleri ve diğer bitkileri çizmeden önce gayet kapsamlı bir gözlemde bulunduğu çıkarımını yapma imkanı verir. Ancak bunları tabloya aktarırken bir sanat eserinin öğeleri olarak çizmiştir ve resme bakan bir insan da bu öğelerden estetik bir haz duyar. Dolayısıyla bir sanatçı, eserinin hammaddesi için bilimsel bir metot kullanmış olsa bile nihayetinde ortaya çıkan eser bilimsel bir yapıt olmaz. Sanat bu bakımdan kapsayıcıdır.
} 
"Güzel sanat yalnız bu kendi özgürlüğü içinde hakiki biçimde sanat olur ve o ancak kendisini din ve felsefe ile aynı alan içerisine yerleştirdiği zaman ve ilahi olan'1, insanlığın en derin ilgilerini ve tinin en kapsamlı hakikatlerini zihinlerimize getirmenin ve ifade etmenin yalnızca bir yolu olduğu zaman en yüksek ödevini yerine getirir” (Hegel, 2019: 6-7).

Croce'nin düşüncesinin Hegel'in düşüncesinden en temel farklarından biri, felsefesinde herhangi bir teolojik öğe bulunmamasıdır. Dolayısıyla onda sanatın dinle kesiştiği bir nokta yoktur. Ancak her ikisinde de "Güzel” Tin'in insan için anlamlı hale gelerek ifade edilmesidir. Croce'nin yine ayrıldığı ve özgüllüğe ulaştığı nokta bu ifadenin neredeyse tüm felsefenin omurgası olmasıdır.

Sanatçının nasıl ele alındığına baktığımızda yine farklı bir durumla karşılaşmayız:

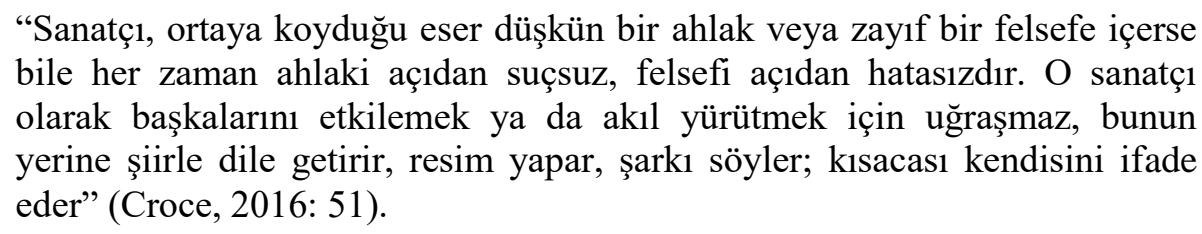

Bu satırlar yine sanatın, yani Tin'in teorik kısmının temelini teşkil eden sezgisel etkinliğin, zihinsel olan ve pratik olan üzerindeki kapsayıcılığını göstermektedir. Bu düşünceler de Hegel'den gelmiş görünüyor:

"[B]ir sanatçının üretici hayalgücü, büyük bir tinin ve yüreğin hayalgücüdür, tasarımların ve şekillerin kavranmasıdır ve yaratılmasıdır ve gerçekten de en derin ve en tümel insan ilgilerinin betimsel ve tamamıla belirli duyusal biçim içinde sergilenmesidir" (Hegel, 2019: 17).

İşte bu duyusal biçim sanat eseri ve sanatsal etkinliğin Tinsel içeriğinin bu dünyada ortaya konmasını ifade eder. Croce için ise biçim ifadedir ve şairi şair; ressamı ressam, yani sanatçıyı sanatçı yapan öğedir (Croce, 1965: 25). Demek ki en genel anlamıyla sezgi, sanatçıyı sanatçı, daha da ötesinde insanı insan yapan şeydir, çünkü bu, Tin'in anlamlı hale gelmesinin biricik ölçütüdür.

Croce'nin çizdiği çerçevede sezgi hem sanatçıya hem de sıradan insana ait olarak betimlenir: "genelde sanatsal olarak kabul edilen sezginin, gündelik sezgiden daha yoğun bir sezgi olarak ayrılması kabul edilemez.” (Croce, 1965: 13). 


\begin{abstract}
"Sanatı sezgi bilgisiyle özdeşleştirmemize sıkıca sarılmalıyız çünkü sanatın bilimi olan Estetiğin sanatın gerçek doğasını ortaya koymaktan alıkoyan temel sebepler arasında, sanatın insan doğasındaki gerçek köklerinin genel Tinsel hayattan koparılması, dolayısıyla sanatın özel bir işlev veya aristokratik gruba ait hale getirilmesi yatar" (Croce, 1965: 14).
\end{abstract}

Bu noktada Patankar'ın değineceğimiz bir tespiti çok anlamlıdır. Ona göre Croce

\begin{abstract}
"Sezginin tüm insanların erişimine açık olduğunu düşünür gibi görünmektedir. Neredeyse durmaksızın sezgisel etkinlikte bulunduğumuz söylenmiştir. Ancak gözlem bize, Croce'nin bu fikrini abarttığını kanıtlayacaktır. Sıradan insan genellikle gerçek dünyayı keşfetmekle meşguldür. Bu yüzden sürekli olarak, gördüğü şeylerin varlığını açıklar gibi görünür. Başka bir deyişle o, sürekli olarak bir şeyler algılar. Sıradan insanın sezgisel tavır takındığı durumlar çok nadirdir ve o bu tavra ulaşmak için de özel çaba göstermek zorundadır. Sezgisel tavır Croce'nin öne sürdüğ̈̈ gibi doğal ve kendiliğinden gelmez" (Patankar, 1962: 117).
\end{abstract}

Aslında Patankar çok göz önünde olan ama idealist bir felsefeye karşı söylemesi belli ölçüde cesaret isteyen bir noktayı vurgulamaktadır: Herkes biraz şair ya da biraz ressam değildir. Dahası çoğu insan böyle değildir. Nitekim üstteki sözlerin sahibi Croce güzelin ifadesi üzerine konuşurken şu satırları da kaleme alır: “Örneğimizi, bize daha yakın ve ulaş1labilir olduğu için söz alanından seçtik, çünkü hepimiz konuşuruz ancak hepimiz çizim ya da resim yapmayı"” (Croce, 1965: 118-119). O halde Croce herkesin ressam, heykeltıraş, müzisyen olamadığını kabul eder, fakat herkesin sözcüklerle iletişim kurmak zorunda olduğunu göz önünde bulundurarak aslında yazı sanatlarını bir bakıma indirgemeci bir yaklaşımla ele almış olur. Herkesin şair doğduğu iddiasının temelinde yatan nokta budur. Ona göre şiir "ne duygu ne imge ne de ikisinin toplamıdır; şiir 'duygunun temaşası' veya 'lirik sezgi' veya (aynı anlama gelen) 'saf sezgi' dir” (Croce, 2014). Croce nesir ile şiir arasındaki farkı da şöyle açıklar:

"Şiir duygunun dilidir, nesir ise zihnin; fakat zihin de somutluğu ve gerçekliği içinde aynı zamanda duygu olduğu için, bütün nesirlerde şiirsel bir yan vardır. Sezgi bilgisi veya ifade ile zihin bilgisi veya kavram, sanat ile bilim, şiir ile nesir arasındaki ilişki ancak iki dereceli bir ilişki olarak tanımlanabilir. Birinci derece ifade, ikinci kavramdır: birincisi ikinci olmadan var olabilir fakat ikincisi birinci olmadan var olamaz. Nesirsiz şiir mümkündür fakat şiirsiz nesir mümkün değildir. ... Şiir 'insan ırkının ana dilidir'; 'ilk insanlar doğaları gereği yüce şairlerdir' (Croce, 1965: 26). 
Bu görüşün kaynağı Vico’dur:

"Eğer uluslar kanunlara dayanarak tesis edilmişse ve bu ulusların kanunları dizeler halinde veriliyse; ve söz konusu ulusların ilk kurumları da benzer biçimde dizeler biçiminde muhafaza edilmişse, bundan mantıken ilk ulusların şairlerden oluştuğu çıkar” (Vico, 2016: 158).

Vico'nun Yeni Bilim eserine burada uzun uzadıya değinmemiz mümkün değildir, zira söz konusu kitap fazlasıyla kapsamlı ve kendi bütünlüğü içinde ele alındığı takdirde anlamlı olan bir yapıttır. Ancak, Vico'dan başlayıp Croce üzerinden Collingwood'a kadar uzanan köprü, çağlar boyunca birbiriyle etkileşimde olan bir geleneğe işaret eder. Dolayısıyla Collingwood'dan geriye doğru gittikçe bu geleneğin ilk nüvelerine rastlamamız bakımından Vico önemlidir. Onun bahsettiği ilk uluslar, ilk insanlar vb. terimler vurguladığımız gibi kendi felsefi dizgesi içinde çok daha anlaşılır hale gelir. Ancak Croce'nin insan ırkının ana dilinin şiir olduğunun altını çizmesi ve Vico'nun da ilk insanların şairler olduklarını öne sürmesi tesadüf değildir. Croce'nin nesir ve şiir ayrımını göz önünde bulundurarak Vico'nun şu satırlarını okursak bu paralellik daha açık hale gelir:

"İnsan ırkının çocukları olan ilk insanlar önce sanatların dünyasını inşa etmişlerdir; ardından uzun bir süre sonra gelen ve bu nedenle ulusların eski insanları olarak kabul edilen filozoflar, bilimlerin dünyasını kurarak insanlığ 1 mükemmel hale getirmişlerdir" (Vico, 2016: 167).

İlk insanlar, yani şairler sanatı; ardından da filozoflar bilimi tesis ederek, insanlığ mükemmel, yani tam veya bütün bir hale getirmişlerdir. Tıpkı Croce'de Tin'in teorik yönünde gündelik (ancak tüm insanlar sözcüklerle anlaştığı için şiirsel olan) sezginin bütün insan etkinliklerinin temelini ve onun ardından gelen kavram bilgisinin, yani felsefenin de teorik etkinliğin bilimi teşkil eden ikinci ayağını oluşturması gibi.

Croce'nin Tin Felsefesi çerçevesinde, nesir ve şiiri bilim ve sanatın ifade biçimi olarak kavrayarak, aynı zamanda insanlığın temel iletişim araçlarının sözcükler olmasından ötürü, bütün insanların pay aldığı bir ifade etkinliği biçiminde ortaya koyması kendi içerisinde oldukça tutarlıdır. Ancak şiir sırf sözcüklerden oluştuğu için tüm insanların birer şair olarak doğduğu önermesini öne sürmek ne kadar tutarlıdır? 
Dahası herkes çizim yapmaz iken sözcüklerle iletişime geçer; fakat büyük bir ressam olan Van Gogh ile Dante arasında nasıl bir fark gözetmemiz gerekir? Yine Estetica'da Croce şöyle der:

"Dante'yi değerlendirmek için, kendimizi onun seviyesine çıkarmamız gerekir: ampirik olarak ne bizim Dante olmadığımız ne de Dante'nin biz olmadığı çok iyi anlaşılmalı. Fakat o temaşa ve yargı anında, ruhumuz şairinkiyle bir olur ve o anda Dante'yle biz bir ve aynı şey oluruz" (Croce, 1965: 121).

Ancak Patankar'1 tekrar hatırlarsak, burada sormamız gereken soru, gündelik insanın çoğu zaman içinde bulunduğu sıradan algılar ve duyumlar denizi arasında gerçekten de Dante ile bir ve aynı olacak tinselliğe ulaşma ihtimali var mıdır; varsa bile bu ihtimalin oranı tüm insanlar göz önünde bulundurulduğunda ne kadar yüksektir? Bunun ötesinde, sanatın diğer dallarında bunu uygulamanın ne derece mümkün olacağı tartışmalıdır. Çünkü gündelik sezgiyle sanatsal sezgiyi birbirinden ayırmadan, tüm insanlarda Dante gibi bir şairin seviyesine çıkacak gücü görmek bizce problemli bir durum yaratır. Zira "sanat eseri dünyadaki bir soruna cevap değil, hayal gücü sahnesinde kendi sorunları uydurup çözüme kavuşturan bir tasavvur nesnesidir" (Dutton, 2017: 261). Bu aslında şu anlama gelir: Sanat eseri tamamen yaratıcı hayal gücünden ortaya çıkan ve bu nedenle kendi benzersiz doğasını barındıran küçük bir dünyadır. Croce için de dünyayı kavramada temel olan hayal gücü ile burada sözünü ettiğimiz hayal gücü arasındaki en büyük fark budur. Croce'ninki tüm insanlarda ortak bulunan ve bu yüzden olası düalizmlere firsat vermeyen bir hayal gücü iken, sanat eserini ortaya çıkaran ve her çıkardığı eserde, özgül sorunlar barındıran sanatsal hayal gücü ise sayısız entiteyi ortaya koyan bir yaratıcılığa işaret eder.

\section{Sonuç}

Croce'nin sanatı temelde sezgi-ifade özdeşliğini merkeze koyarak ele alması ve şiiri kavrayış biçimi, özellikle artık biçim ve içerik tartışmalarının ötesine geçen modern sanatın mevcudiyeti de göz önünde bulundurulduğunda oldukça problemli görünmektedir. Sanat eseri mutlaka onu anlayacak özneler olmadan bir anlam ifade 
etmez çünkü “felsefeyle özünde bağı olmayan, belli bir felsefi anlam taşımayan ve belli bir toplumsal ideali dile getirmeyen tek bir sanat yoktur. ... Sanat kendi özü gereğince, felsefidir" (Ziss, 2016: 53). Ancak sanatın özünde felsefi, yani insani bir etkinlik olması, herkesin içinde sanatçı idealinden pay almış bir ruh bulunduğuna dair idealist bir yaklaşımı temellendirmeye yetmez. Çünkü bu sözü edilen toplumsal ideal, pek çok farklı türde olabilir. Özünde felsefi olan bir etkinliğin ise salt estetik hazza indirgenmesi mümkün değildir. "Yaratıcılık ve yenilik sanatın kurallar ve rutinlerce idare edilmeyen yönü olarak bireysellik ve dehaya ev sahipliği yapar. Sanatta hayal gücü yeteneği yaratıcılığı gösterme becerisiyle ölçülür” (Dutton, 2017: 67). Sanat eserini anlamak (eğer böyle bir deyiş mümkünse) bu yaratıcılığın farkına varmakla mümkündür. Ancak bu farkına varış, Croce'nin Dante örneğindeki gibi sanatçının kendisiyle bir ve aynı olmak biçiminde fazlasıyla ideal bir biçimde olamaz. Çünkü böyle bir durumda söz konusu hayal gücü sanatçıya ait olmaktan çıkar. Her şeyin ötesinde, Croce'nin "Dante'nin seviyesine çıkmak" ifadesini kullanması da şiir, yani ona göre tüm insanlarda ortak olan yeti söz konusu olsa dahi, bazı insanlarda bu yetinin çok daha yetkin olduğunu kabul ettiğini gösterir. Şüphesiz, sanatı bir zümreye ait bir etkinlik olarak görmek de son derece problemli bir bakıştır, ancak Croce'ninki kadar idealist bir yaklaşım da vurgulamış olduğumuz ve kendisinin de bazen satır aralarında kabul ettiği gibi, sanatın benzersizlik içeren doğasına aykırı görünmektedir. Belki, gündelik insanın geri kalan tüm özelliklerini görmezden gelerek, herkeste bir şair ya da sanatçı doğası olduğunu düşünmek yerine, Dutton'ın vurguladığı gibi, "Sanat felsefesinin ihtiyac1 olan, sanatı insan hayatında doğal olarak ortaya çıkan bir dizi eylem, nesne ve deneyim olarak ele alan bir yaklaşım olmasıdır" (Dutton, 2017: 63), demek daha makuldür. 


\section{KAYNAKÇA}

CARR, H. W. (1917). The Philosophy of Benedetto Croce: the problem of art and history by $\mathrm{H}$. Wildon Carr, London: Macmillan.

CARUS, P. (1916). CROCE'S USE OF THE WORD "INTUITION." The Monist, 26(2), 312-315. Retrieved July 17, 2020, from www.jstor.org/stable/27900592

CROCE, B. (1990). Estetica come scienza dell'espressione e linguistica generale: teoria e storia. Milano: Adelphi.

CROCE, B. (2014, August 14). Benedetto Croce on aesthetics. Retrieved May 17, 2020, from https://www.britannica.com/topic/Benedetto-Croce-on-aesthetics1990551

CROCE, B. (1921). History Its Theory and Practice. (J. E. Spingarn, Ed.). New York: Harcourt, Brace and Company

CROCE, B. (1965). Asthetic as science of expression and general linguistic, çev. D. Ainslie, The Noonday Press.

CROCE, B., Bodei, R., \& Fudemoto, H. (2016). Breviary of Aesthetics. Toronto: University of Toronto Press. doi: https://doi.org/10.3138/9781442684089

DIMLER, G. R. (1963). "Creative Intuition in the Aesthetic Theories of Croce and Maritain". The New Scholasticism, 37(4), 472-492. https://doi.org/10.5840/newscholas19633744

DOORLY, P. (2019). Sanatta Hakikat- Niteliğin Dönüşü, çev. A. Çavdar, İstanbul: Ayrıntı Yayınları.

DUTTON, D. (2017). Sanat İçgüdüsü Güzellik, Zevk ve Insan Evrimi, çev. M. Turan, İstanbul: Ayrıntı Yayınları.

HEGEL, G.W.F. (2019). Estetik Güzel Sanat Üzerine Dersler, çev. T. Altuğ, H. Hünler, İstanbul: Kırmızı Kedi Yayınevi.

MOSSE, G. (1996). "Fascist Aesthetics and Society: Some Considerations", Journal of Contemporary History, 31(2), 245-252. Retrieved May 3, 2020, from www.jstor.org/stable/261165

PATANKAR, R. B. (1962). "What does croce mean by "expression"?" The British Journal of Aesthetics, 2(2), 112-125. doi:10.1093/bjaesthetics/2.2.112 Yayınları.

TUNALI, İ. (1973). B. Croce Estetik'ine Giriş. İstanbul: İ.Ü. Edebiyat Fakültesi

VICO, G., Bergin, T.G., \& Fisch, M.H. (2016). The New Science of Giambattista Vico: Unabridged Translation of the Third Edition (1744) with the addition of "Practic of the New Science". Ithaca: Cornell University Press. muse.jhu.edu/book/57749. 
Yavuz KILIÇ - Burak SAYIN. "Benedetto Croce'nin Felsefesinde Sezgi-İfade Özdeşliği Bakımından Sanatın Konumu," Kaygı, 19(I1)/2020: 636-653.

ZISS, A. (2016). Estetik Gerçekliği Sanatsal Özümsemenin Bilimi, çev. Y. Şahan, İstanbul: Hayalperest Yayınevi. 